\title{
The Reflection of Social Responsibility Accounting Application in the Insurance Companies-Jordan to Increase Their Earnings
}

\author{
Ali Mustafa Magablih ${ }^{1}$ \\ ${ }^{1}$ Irbid National University, Jordan \\ Correspondence: Ali Mustafa Magablih, Irbid National University, Jordan. E-mail: alimagablih@yahoo.com
}

Received: April 28, 2017

Accepted: May 16, 2017

Online Published: June 25, 2017

doi:10.5539/ijef.v9n7p242

URL: https://doi.org/10.5539/ijef.v9n7p242

\begin{abstract}
Identification reflection of the researcher by the Jordanian insurance companies increasing their revenues, for the purposes of the study were the use of the descriptive approach to identify analytical and distributed on a random sample of financial managers and senior officials in those companies and the volume of the questionnaires distributed (40) Identification of recalled (40). The study came to a set of results, the most important of which are the following: there is no adequate awareness and understanding of the concept of responsibility and accountability in the insurance companies in Jordan.

There is no full and effective application of the concept of responsibility and accountability in the insurance companies in Jordan.

There is no understanding of the interaction of the staff of the concept of responsibility and accountability in the insurance companies in Jordan.

There is a relationship between the understanding and application of social responsibility and increasing income and to find if there is a relation between the earning and the accounting for social responsibility.
\end{abstract}

Keywords: social, responsibility, accounting, insurance, earning

\section{Introduction}

The flow of investors on Jordan to create branches for their companies within the Kingdom in order to take advantage of this attractive conditions; to maintain these investments and stimulate a greater number of investors to establish projects in the kingdom, the establishment of insurance companies. Was the first insurance company in Jordan in 1951, successive beyond the establishment of other companies; in view of the increasing number of these companies, the government considered the establishment of the Jordanian association of insurance companies in 1956, in order to regulate the insurance sector in Jordan. The General Assembly continued the work and developed. In 1989 the Jordanian union was founded for the same purpose. With the expansion and development of the insurance companies and awareness of the importance of modernization, founded the organization of the insurance sector, which changed its name to the Insurance Authority in 2002 to organize the work of these companies.

The insurance companies in Jordan are subject to monitoring and regulation by the Insurance Authority which is a quasi-governmental regulatory body, in addition to that there are external auditing companies plays the same role in the control of the accounting system and responsibilities entrusted to these companies through an internal control system subject to everyone in the company, or what is known as the responsibility, where accountability responsibility has become an integral part of any effective system of accounting.

When the company's application of the concept of responsibility accounting company be more reassuring to investors, lenders and others.

Accounting responsibility as a concept means that a system designed to collect the data reflecting the activity of every official during a certain period compared with specific responsibilities in advance and dissemination of reports, in order to assess the person and his ability to control.

There is defined as the method of accounting regulatory to serve the department in the evaluation of the performance of officials in the administrative levels in terms of the extent of their commitment to costs and revenues, and the objectives of the reports. 
This research was conducted to determine the extent of the obligation of insurance companies to apply the activation of this concept.

\subsection{Problem Study}

In view of the suffering of the world now as a result of the global financial crisis which engulfed in all countries of the world without exception, it is the insurance companies and the application of the concept of responsibility and accountability in all its clauses, because of its geographical spread, where many of the insurance companies outside the state and establish branches in many of the countries of the world.

Referring to what we in the previous paragraph on the problem of the existence of the global financial crisis, as the most important reason in this crisis lack of control and legislation to punish the companies abandoned these insurance companies. It has become important not only to the existence of a system of staff accountable in such a system, where multiple staff in the insurance companies and the volume of work of the supervisory regime needs a high degree of efficiency specifies the duties and responsibilities of each person, the insurance companies were the biggest victim of this crisis, where the obligation to pay the installments for the believers have and did not have adequate liquidity to ensure the monthly installment in what was called at the time of the real estate mortgage crisis.

Accountability and responsibility must be the focus of the so-called good governance which can be summarized as monitoring the performance of managers in running the company, where many of the managers in companies have left their responsibilities fizzling out to achieve personal gains at the expense of the company.

Now after the review of the problem of the study we can shed light over them and identify aspects through the following questions:

$>$ Are you aware of the workers in the insurance companies the concept of responsibility and accountability?

$>$ What is the extent of the application of the concept of responsibility and accountability in the insurance companies?

$>$ What is the impact on the performance of insurance companies from the application of the concept of responsibility and accountability?

$>$ What are the implications of the application of the concept of responsibility and accountability on the accuracy of accounting information?

\subsection{The Objectives of the Study}

$>$ A statement of the understanding of the concept of responsibility and accountability in the insurance companies.

$>$ A statement of the extent of the application of the concept of responsibility and accountability in the insurance companies.

$>$ Identify the vulnerability of workers' performance, the application of the concept of responsibility and accountability.

$>$ The statement of the impact of the application of the concept of responsibility and accountability on the accuracy of accounting information.

\subsection{The Importance of the Study}

The importance of the study that most of the countries of the world started the application and the introduction of the concept of responsibility accounting to accounting systems to companies in the errors that may lead to its bankruptcy; hence the imbalance in the economy, as happened recently in the global economic crisis, where we are going in this Search How to apply major world companies to hold responsibility, especially in the insurance companies even have the opportunity to apply the concept of responsibility and accountability in the Jordanian insurance companies.

This study highlights the importance of the fact that the concept of responsibility and accountability, I mean, a large number of relevant authorities, where they can benefit from the results of the study, the administration and staff in companies are very concerned over access to such studies, study and apply what suits them in accordance with the activity of their companies and the laws of the State in these companies.

Beyond the importance of the study to the attention of the administration to shareholders and investors, where 
the concept of accountability and responsibility to monitor the performance of the companies concerned and helps shareholders and investors to take their decisions to a great extent.

\section{Previous Studies}

A growing interest in research on the concept of responsibility, accountability is one of the hot issues in the current global economic environment, especially after the economic crisis. The many countries of the world to conduct studies on the level of the public sector and representatives of government institutions, the private sector and representatives of companies of various kinds, either we researchers have found some Arab and foreign studies and research which dealt with the liability of the various aspects of accounting and some have dealt with the application of this concept in the insurance companies.

1) Saidiya study the Navigator (1986) entitled "The role of the accounting system the responsibility in raising the productivity and efficiency".

The goal of the researcher in this study:

Highlight the role of the accounting system the responsibility in raising the productivity and efficiency of the system in terms of effective control of the costs.

Setting performance standards and link performance responsibility centers, which contributes to reducing costs on the one hand and improving the quality of the performance and efficiency of high productivity on the other.

The researcher touched on in this study to talk about the components of the liability of the accounting system, where the presence of a sound organizational structure and identify a clear, precise and all the authorities and responsibilities; it is the responsibility accounting system on the basis of the Division established to units the supervision in the framework of the organizational structure of the facility, to determine for each person responsible for his duties and functions. Even accounting could be based on the implementation of these tasks, the officials should be given adequate powers to oversee the implementation.

Promoted realistic researcher studying the use of the budget, for example, in measuring the Accountability Responsibility; where the administration needs as substantive means that include clarity and detail destruction, plans and policies are translated literally. The budget is an effective tool in monitoring the implementation and the accountability of officials, as well as one of the criteria used to measure the actual performance and comparing it to the performance required, because it determines the deviations and the persons responsible for these deviations.

The researcher concluded that some of the recommendations, the most important companies available in the system and raise the management reports on actual performance and comparing it to the trick.

2) Kasharmeh study made clear (2004) entitled "Measuring the possibility of the application of the Accountability Responsibility in the Jordanian government."

This study aimed to:

Recognize the reality of the application of the accounting system the responsibility in the Jordanian Government.

This study theoretical aspects relating to this system to employ in the service of governmental accounting and application, and thus has been the identification of the basic ingredients to hold responsibility, as the study to the general budget in Jordan.

In order to achieve the objectives of the study, the researcher design of identification is composed of two sections to obtain the data. This resolution included data on the characteristics of the respondents and the application of the responsibility accounting system in the Jordanian Government. The results have been analyzed using descriptive statistical methods such as the median and the standard deviation, as well as variance analysis was used.

The results of the study showed several things, the most important:

1) The need for attention to the administrative control of the sections and centers within the Organization.

2) The use of the concepts and tools for cost accounting and management accounting in the governmental systems.

3) The Division of Administrative Unit cost and revenue centers.

The study recommended several proposals, the most important of which was the need to provide the necessary ingredients for the application of the accountability of responsibility in the government sector and the sessions of the rehabilitation of the employers and employees of the relationship. 
3) The study of Omar Medh (2003) entitled "Responsibility accounting system in the public shareholding companies, the realities and aspirations".

This study aimed to achieve the following objectives:

1) The statement of the evolution of the concept of responsibility and relevance of accounting, where the oversight and evaluation of performance.

2) The study of the elements of the application of the responsibility of the accounting system, where the administrative and planning budgets responsibility centers, and the measurement of actual performance and comparing it to the planning, budgets and performance report responsibility centers and the availability of an effective incentive system.

3) The reality of the practical application of the accounting system of responsibility in the Jordanian public shareholding companies.

Follow in the preparation of the curriculum, the researcher discussed this is rendered through reference to Arab and foreign references, research and studies of interest to punish responsibility, also adopted approach to know the contributions of accounting thought and practice in the area of responsibility and accountability in the Jordanian public shareholding companies. The research also included several hypotheses that included the main ingredients of the proposed regime to hold responsibility, where the researcher tested through the resolution prepared for this end and distributed them to all the Jordanian public shareholding companies listed on the Amman financial Market for 2001.

Finally, the researcher presented a set of conclusions and recommendations the process to overcome the weaknesses in the practical application of the Accounting responsibility in the Jordanian companies.

\section{The Hypotheses of the Study}

In this research, we examine several hypotheses in relation to the concept of responsibility and accountability in the Jordanian insurance companies:

\section{The first hypothesis}

There is adequate awareness and understanding of the concept of responsibility and accountability in the insurance companies in Jordan.

\section{The second hypothesis}

There is no full and effective application of the concept of responsibility and accountability in the insurance companies in Jordan.

\section{The third hypothesis}

There is no understanding of the interaction of the staff of the concept of responsibility and accountability in the insurance companies in Jordan.

\section{The fourth hypothesis}

Earnings are not affected by insurance companies the application of the Accountability Responsibility.

\section{Study Methodology}

Journals, Books, the Internet was adopted by the court to cover the theoretical side, as for the practical side and distribution has been designed to identify the financial managers and directors of insurance companies.

The processing and distribution, and to identify the insurance companies and then analyze the linkage of results to reach a conclusion with regard to the research, which we are discussing. and distributed on a random sample of financial managers and senior officials in those companies and the volume of the questionnaires distributed (40) Identification of (40).

\subsection{Methods of Data Analysis}

The normal distribution test: to distribute the results in an objective and non-existence of anomalous results and great deviation.

The descriptive statistical methods: such as the average and the standard deviation.

\subsection{Field Study of Statistical Analysis}

Distributed (40) identification of the sample study and retrieval (40) identification of valid for the purposes of statistical analysis, any recovery rate reached (100\%), a compilation of these questionnaires, and then enter the 
data obtained on the Statistical Analysis System (SPSS) and including the following:

\subsubsection{Description of the Demographic Characteristics of the Study Sample}

Table 1. Distribution of the sample by age

\begin{tabular}{|ccc|}
\hline Age & Frequencies & Percentage \\
\hline Less than 30 & 8 & $20 \%$ \\
\hline From $31-40$ & 9 & $22.5 \%$ \\
\hline From $41-50$ & 15 & $37.5 \%$ \\
\hline From $51-60$ & 5 & $12.5 \%$ \\
\hline More than 61 & 3 & $7.5 \%$ \\
\hline The total & 40 & $100 \%$ \\
\hline
\end{tabular}

Through the previous table shows us that most of the sample members aged between (41-50 years), and their proportion (37.5\%), and the category has increased from 61-year-old regular share at least in these questionnaires, where their number does not exceed three people at a rate $(7.5 \%)$.

Table 2. Distribution of the sample by sex

\begin{tabular}{|ccc|}
\hline Sex & Frequencies & Percentage \\
\hline male & 32 & $80 \%$ \\
\hline Female & 8 & $20 \%$ \\
\hline The total & 40 & $100 \%$ \\
\hline
\end{tabular}

Through the previous table shows us that most of the members of the sample of males, where the number and proportion of individuals (32) (80\%), while the number of females (8) members of the percentage (20\%), which indicates that most of the views and answers obtained are males.

Table 3. Distribution of the sample members according to the specialization

\begin{tabular}{|ccc|}
\hline Specialization & Frequencies & Percentage \\
\hline Accounting & 13 & $32.5 \%$ \\
\hline management & 8 & $20 \%$ \\
\hline Computer & 6 & $15 \%$ \\
\hline A computer & 1 & $2.5 \%$ \\
\hline Banking and & 8 & $20 \%$ \\
\hline The law & 3 & $7.5 \%$ \\
\hline Others & 1 & $2.5 \%$ \\
\hline The total & 40 & $100 \%$ \\
\hline
\end{tabular}

Through the previous table shows us that most of the members of the sample were of the campaign were accounting certificate (13) and (32.5\%), followed by specialized management and finance the percentage (20\%) of the total sample, and the rest of the percentages were distributed among the remaining specialties at varying rates.

Table 4. Distribution of the sample members according to the Academic qualifications

\begin{tabular}{|ccc|}
\hline Academic qualifications & Frequencies & Percentage \\
\hline Diploma & 1 & $2.5 \%$ \\
\hline Bachalorea & 19 & $47.5 \%$ \\
\hline Higher Diploma & 5 & $12.5 \%$ \\
\hline Master & 5 & $12.5 \%$ \\
\hline Others & 10 & $25 \%$ \\
\hline The total & 40 & $100 \%$ \\
\hline
\end{tabular}

Through the previous table shows us that most of the members of the sample were of a first university degree 
(Bachelor) where the number (19), and their proportion (47.5\%), followed by the Higher Diploma Master equal rate for each of them $(12.5 \%)$

Table 5. Distribution of the sample by function

\begin{tabular}{|ccc|}
\hline Function & Frequencies & Percentage \\
\hline Administrative Manager & 13 & $32.5 \%$ \\
\hline Director & 11 & $27.5 \%$ \\
\hline Others & 16 & $40 \%$ \\
\hline The total & 40 & $100 \%$ \\
\hline
\end{tabular}

From the table above it is clear to us that the members of the sample are distributed relatively evenly on the categories mentioned in the resolution, it is clear that we (13) individuals were administrative managers by up to $(32.5 \%)$, and (11) members of financial managers by up to $(27.5 \%)$, and the other functions taken percentage $(40 \%)$ of the total number of members of the sample.

Table 6. Distribution of the sample members as experience

\begin{tabular}{|ccc|}
\hline The Experience & Frequencies & Percentage \\
\hline Less than 5 Years & 9 & $22.5 \%$ \\
\hline From 6-10 years & 10 & $25 \%$ \\
\hline More than 10 years & 21 & $52.5 \%$ \\
\hline The total & 40 & $100 \%$ \\
\hline
\end{tabular}

From the table above it is clear to us that most of the members of the sample were within the category g (10 years and above), where the number of (21) members of the sample members whose number (40) Individuals formed or $(52.5 \%)$.

4.2.2 Discussion of the Hypotheses of the Study

After a profile of the sample, the members of the sample answers to the questions of the study, use the level five in answering questions of the resolution, according to the following steps:

5= Strongly Agree; $4=$ agree; $3=$ agree moderately; $2=$ not agree; $1=$ Strongly Disagree

\section{The answers were used averages of the sample members as follows:}

(1-2.5) not to approve

(2.6-3.5) neutrality.

(3.6-5.0) Approval

The researcher found that the extent of the presence or absence of variables are according to the specific rule that approval toward the paragraph be positive if the arithmetic average of paragraph (greater than 3.5), a negative trend if the arithmetic average of paragraph less than (2.6).

The first hypothesis: There is no adequate awareness and understanding of the concept of responsibility and accountability in the insurance companies in Jordan:

Discuss this hypothesis, the answers to the members of the sample on a series of questions relating to this hypothesis which measure the trends of the sample members, the following table shows:

Table 7. The average answers to the members of the sample to the first group of questions and the standard deviation

\begin{tabular}{|c|c|c|c|}
\hline No. & Paragraph & average & The Standard Deviation \\
\hline & $\begin{array}{l}\text { The company included in the organizational structure is evidence of the use of the concept of } \\
\text { responsibility and accountability. }\end{array}$ & 2.42 & 0.81 \\
\hline & $\begin{array}{l}\text { There is a deterrent measures to support and consolidate the concept of responsibility and } \\
\text { accountability of doing wrong or violation. }\end{array}$ & 2.58 & 0.84 \\
\hline 3. & The company provides a list covering the intention to punish the full responsibility. & 2.60 & 0.84 \\
\hline & The company's interest to give an idea of the concept of responsibility and accountability to staff. & 2.73 & 0.99 \\
\hline & Average & & 2.6 \\
\hline
\end{tabular}




\section{Notes from the table as follows:}

1) The similarity of answers to the members of the sample on this group of questions there was stable in the trends, where we find that some of the answers are not to approve some heads toward approval of a medium.

2) Most of the sample members agreed not to approve that there is adequate awareness and understanding of the concept of responsibility and accountability in the insurance companies in Jordan, the arithmetic average of (2.6).

3) Through the answers to the members of the sample on this group of questions, which were distributed among the non-approval and approval to a medium, we find that the first hypothesis is acceptable to any that there is not enough awareness and understanding of the concept of responsibility and accountability in the insurance companies in Jordan.

The second hypothesis: there is no full and effective application of the concept of responsibility and accountability in the insurance companies in Jordan.

Discuss this hypothesis, the answers to the members of the sample on a series of questions relating to this hypothesis which measure the trends of the sample members, the following table shows:

Table 8. The average answers to the members of the sample on the second group of questions and the standard deviation

\begin{tabular}{|c|c|c|c|}
\hline No. & Paragraph & average & Standard Deviation \\
\hline 5. & $\begin{array}{l}\text { The Jordanian insurance law provides the necessary insurance companies to activate the } \\
\text { Accountability Responsibility. }\end{array}$ & 2.38 & 0.84 \\
\hline 6. & The concept of accountability reflects responsibility for the credibility of the company. & 2.35 & 0.77 \\
\hline 7. & Apply the concept of responsibility and accountability to specific individuals. & 2.73 & 1.11 \\
\hline 8. & $\begin{array}{l}\text { The application of the concept of responsibility accounting adds any value to your business } \\
\text { referring in the company. }\end{array}$ & 2.25 & 0.71 \\
\hline 9. & $\begin{array}{l}\text { More than the concept of responsibility accounting and its application of the credibility of the } \\
\text { information insurance companies. }\end{array}$ & 2.08 & 0.69 \\
\hline 10. & Apply the responsibility accounting system in the insurance companies in particular. & 3.18 & 0.98 \\
\hline 11. & The application of accounting already insurance companies responsibility. & 2.78 & 0.73 \\
\hline 12 & $\begin{array}{l}\text { Does not apply the concept of responsibility accounting to frustrate the workers in the } \\
\text { company. }\end{array}$ & 2.42 & 0.93 \\
\hline 13. & $\begin{array}{l}\text { Contribute to the accountability of responsibility in the application of the insidious system of } \\
\text { objectives by linking planning budgets and responsibility centers in the company. }\end{array}$ & 2.58 & 0.78 \\
\hline 14. & $\begin{array}{l}\text { The application of the concept of the accountability of responsibility to create a sense of } \\
\text { awareness of lower levels of supervision in the organization. } \\
\text { Average }\end{array}$ & 2.55 & 0.85 \\
\hline
\end{tabular}

\section{Notes from the table as follows:}

1) Answers to the sample members did not differ on this group of questions there was a clear difference, where most headed toward the non-approval.

2) Most of the sample members agreed that the Jordanian Insurance Authority, insurance companies are not required to activate my account, accounting responsibility average (2.38).

3) Most of the members of the sample believes that there is a relationship between the use of the accountability and responsibility of the management system goals and average my account amounted to (2.58).

4) Most of the members of this sample agreed that there is no relationship between responsibility and creating a sense of accountability and awareness of lower levels of supervision in the arithmetic average of the Organization (2.55).

Through the answers to the members of the sample on a series of questions relating to the second, which mostly headed toward non-approval, i.e. that there is full and effective application of the concept of responsibility and 
accountability in the insurance companies in Jordan. Thus, the hypothesis is accepted.

The third assumption: there is no application of the understanding of the interaction of the staff of the concept of responsibility and accountability in the insurance companies in Jordan.

Discuss this hypothesis, the answers to the members of the sample on a series of questions relating to this hypothesis which measure the trends of the sample members, the following table shows:

Table 9. The average answers to the members of the sample on the third group of questions and the standard deviation

\begin{tabular}{llcc}
\hline No. & \multicolumn{1}{c}{ Paragraph } & average & Standard Deviation \\
\hline 15. & The focus of the company's general manager to request reports focus on accountability in the & 2.55 & 0.68 \\
& whole responsibility. & 2.48 & 0.78 \\
16. & auditor and the results of the accounting system of responsibility into account in his report. & 2.58 & 0.81 \\
17. & The distribution of the responsibilities of the staff according to the functional grades. & 0.98 \\
18. & The surveillance system of responsibility accounting problems and difficulties facing the & 2.58 & 0.74 \\
& Department and propose ways to address them. & 2.38 & $\mathbf{2 . 5 1}$ \\
19. $\quad$ Affect the application of the Accountability Responsibility positively on the performance of & \\
& insurance companies. \\
& Average
\end{tabular}

\section{Notes from the table as follows:}

1) Answers to the sample members did not differ on this group of questions there was a marked contrast, going mostly toward approving the negative trend.

In all paragraphs of this group of questions we find that most of the sample members agreed not to approve it, and thus we can say that there is no understanding of the interaction of the staff of the concept of responsibility and accountability in the insurance companies in Jordan that the third assumption of an exiled completely.

The fourth hypothesis: Earnings are not affected by insurance companies the application of the Accountability Responsibility.

Discuss this hypothesis, the answers to the members of the sample on a series of questions relating to this hypothesis which measure the trends of the sample members, the following table shows:

Table 10. The average answers to the members of the sample on the fourth group of questions and the standard deviation

\begin{tabular}{|c|c|c|c|}
\hline No. & Paragraph & average & Standard Deviation \\
\hline 20. & $\begin{array}{l}\text { The company collects data on staff in specific periods of the course evaluation and } \\
\text { accountable. }\end{array}$ & 2.93 & 0.92 \\
\hline 21. & $\begin{array}{l}\text { The aim of the concept of accountability responsibility to the control and evaluation of staff } \\
\text { performance improvement as a result of different management accountable for their actions. }\end{array}$ & 2.42 & 0.87 \\
\hline 22. & $\begin{array}{l}\text { Help responsibility accounting system to assess the performance of each level of } \\
\text { management levels in the organizational structure of the independently. }\end{array}$ & 2.63 & 0.77 \\
\hline 23. & $\begin{array}{l}\text { The company officials do not resort to the so-called budget gap when estimating revenues } \\
\text { and costs. }\end{array}$ & 2.80 & 0.85 \\
\hline 24. & $\begin{array}{l}\text { Accounting System relies on the responsibility to find a direct relationship between the } \\
\text { elements of costs and revenues and the persons responsible for its establishment. }\end{array}$ & 2.63 & 0.95 \\
\hline \multirow[t]{2}{*}{25.} & $\begin{array}{l}\text { The company is the concept of responsibility and accountability as part of the surveillance } \\
\text { system of the company. }\end{array}$ & 2.38 & 0.98 \\
\hline & Average & & 2.63 \\
\hline
\end{tabular}

\section{Through the previous table shows us the following:}

1) Members of the sample did not differ answers to this set of questions, we find that some heads toward approval of moderate and others toward the non-approval. 
2) Most of the sample members also agreed to approve moderately on paragraph which says: "The company's officials resort to the so-called budget gap when estimating the income and costs", the arithmetic average of (2.6).

Through the previous answers averages and trends of the sample members to what came in the fourth paragraph, we find that it is not affected by the performance of insurance companies the concept of responsibility and accountability thus proving the hypothesis.

\section{Results and Recommendations}

\subsection{Results}

1) There is adequate awareness and understanding of the concept of responsibility and accountability in the insurance companies in Jordan.

2) There is no full and effective application of the concept of responsibility and accountability in the insurance companies in Jordan.

3) There is no understanding of the interaction of the staff of the concept of responsibility and accountability in the insurance companies in Jordan.

4) Is not affected by the performance of insurance companies the concept of responsibility and accountability.

5) There is a relationship between the understanding and application of social responsibility and increasing income accounting

\subsection{Recommendations}

1) There must not be a deterrent measures to support and consolidate the concept of responsibility and accountability of doing wrong or violation.

2) The need does not apply your congregation and the responsibility

3) That does not apply the responsibility accounting system in the insurance companies in particular.

4) We must not focus, general manager of the company to request reports focus on accountability in the whole responsibility.

5) The need for the results of the Checker does not take into account the responsibility accounting system in his report.

6) The need for the collection of data on staff in the periods of their assessment of the book.

7) Should not the company officials resort to the so-called budget gap when estimating revenues and costs.

8) That is the concept of responsibility and accountability as part of the surveillance system of the company.

9) Accountability should be aimed at the concept of responsibility to the control and evaluation of staff performance improvement as a result of different management accountable for their actions.

10) The need to help the responsibility accounting system to assess the performance of each level of management levels in the organizational structure of the independently.

\section{References}

Al-Kahlout, K. M., \& Beheesi, E. M. (2007). Factors affecting the extent of adoption credit officials on financial analysis in the rationalization of the credit decision: Field study on the banks operating in Palestine. Journal of Islamic University.

Anonymous. (2006). Credit analysis and its role in the rationalization of the operations of bank lending: The Bank Syrian industrial application. Library of Tishreen University for Studies and Scientific Research, 28(3).

Barakat, I. M. (2007). the importance of disclosure of the risks of financial transactions related to money laundering in commercial banks, Analytical Study in the light of the theory of social responsibility. Research submitted by the Seventh Annual Scientific Conference, Faculty of Economics and Administrative Sciences, Al Zaytoonah University of Jordan, Amman, Jordan.

Branco, M. R. (2008). Social responsibility disclosure: Study of responding server-which stores or creates resources for the public visibility of Portuguese bank. The Brish Accounting Review, 3. https://doi.org/10.1016/j.bar.2008.02.004

Hammad, T. A. (2000). Financial reports. Amman, Hashemite Kingdom of Jordan. 
Hassan, I. A. (2002). The gap between disclosure in accounting and disclosure in the scrutiny under international accounting standards. Accounting Standards, Regulatory, Legal Accountant Magazine, (7).

Hussein, K. (2008). An analysis of the level of social responsibility accounting disclosure in the Jordanian industrial companies contribute to the General Assembly - An analytical study. Egyptian Magazine Business Studies, 1 .

Jarboa, Y. M. (2001). Accounting for social responsibility. Accounting Theory. Publisher Warraq Printing and Publishing House, Amman - Jordan.

Jennifer, G., \& John, M. (1997). The corporate social performance and corporate financial performance debate. Business \& Society: Founded at Roosevelt University, 36(1), 5-31. https://doi.org/10.1177/000765039703600102

Kandola, P. (2004). Corporate Social Responsibility: Why good people behave badly in organizations.

Macarulla, F., \& Talalweh, M. (2012). Voluntary Corporate Social Responsibility Disclosure: A Case Study of Saudi Arabia. Jordan Journal of Business Administration.

Maher. (2003). The impact of the disclosure of the social responsibility of financial lists in the decisions of the users of these lists, Prospective study Practicals. Master thesis, University of kufah.

Mahoney, L., \& Roberts, R. W. (2007). Corporate social performance, financial performance and institutional ownership in Canadian firms. Accounting Forum. https://doi.org/10.1016/j.accfor.2007.05.001

Mohamed, H. (2002). Social performance measurement and disclosure in the industrial installations. Unpublished Master Thesis, University of Aleppo, the Syrian republic.

Muttakin, M. B., \& Khan, A. (2014). Determinants of corporate social disclosure: Empirical evidence from Bangladesh. Advances in Accounting. https://doi.org/10.1016/j.adiac.2014.03.005

Nofan, Z. (2010). Accounting measurement of the costs of the activities of social responsibility and disclosure in the financial statements and the final of the Jordan Petroleum Refinery Company Limited public contribution. Phd dissertation, University of Damascus.

Yingjun, L., \& Abeysekera, I. (2014). Stakeholders' power, corporate characteristics, and social and environmental disclosure: Evidence from China. Journal of Cleaner Production.

Youssef, M. J. (2007). The extent of the application of measurement and disclosure in accounting for Social Responsibility Corporate financial lists in the Gaza Strip. Journal of the Islamic University, 15(1).

\section{Copyrights}

Copyright for this article is retained by the author(s), with first publication rights granted to the journal.

This is an open-access article distributed under the terms and conditions of the Creative Commons Attribution license (http://creativecommons.org/licenses/by/4.0/). 